\title{
Construction Rehabilitation in Civil Engineering at bachelor degree level: A guideline course
}

\author{
I. Lombillo ${ }^{1}$, M. V. Biezma ${ }^{2}$, L. Villegas ${ }^{3}$
}

\begin{abstract}
In general terms, construction rehabilitation is not sufficiently studied worldwide in Civil Engineering Schools. In this article we propose an international guideline course for Rehabilitation of Constructions envisaged for Civil Engineering students at bachelor degree level. As we live in an increasingly globalized world, the course aims to prepare our students in the same basic concepts, so the course content and its focus can be common for all Civil Engineering programs worldwide. Nevertheless, the course should be considered as a general guideline, so that in each university, special attention should be paid to the topics that are most common due to the varying construction practices, preservation laws and regulations, and legal jurisdiction governing the scope of practice in construction rehabilitation, existing in the region/country in which the university is located. Moreover, in the authors' opinion the guideline course should be focused on existing building types, both significant historic ones and those which make up the day-to-day rehabilitation market.
\end{abstract}

To achieve this, the initial step of the methodology was the study and integration of the results obtained in a survey sent to lecturers in 89 universities in 30 countries around the world. Then, a preliminary grouping was done of topics which could be included in the course, pre-assigning a teaching time to each topic. Later, various renowned experts in the matter audited the tentative guideline course. Finally, based on their opinions and comments, we rewrote the definitive guideline course. Through this course, Civil Engineering students will improve their ability to recognize, analyze, diagnose and solve problems that

\footnotetext{
${ }^{1} \mathrm{Ph} . \mathrm{D}$. Lecturer (corresponding author). Dept. of Structural and Mechanical Engineering. University of Cantabria. Civil Engineering School. Avda. Los Castros s/n, 39005 Santander, Spain. ignacio.lombillo@unican.es

${ }_{2}^{2}$ Ph.D. Professor. Dept. of Science and Engineering of Materials. University of Cantabria. Civil Engineering School. Avda. Los Castros s/n, 39005 Santander, Spain. maria.biezma@unican.es

${ }^{3}$ Ph.D. Full Professor. Dept. of Structural and Mechanical Engineering. University of Cantabria. Civil Engineering School. Avda. Los Castros s/n, 39005 Santander, Spain. luis.villegas@unican.es
} 
commonly appear in the existing buildings, and they will increase their knowledge about maintaining and conserving them.

Subject headings: Buildings; Civil engineering landmarks; Construction; Conservation; Rehabilitation; Renovation; Universities.

Keywords: Construction Rehabilitation; Construction Preservation; Existing Buildings; University; Civil Engineering.

\section{INTRODUCTION}

The conservation of existing buildings is a fundamental principle in the cultural life of modern societies. In recent years, this topic has been the subject of extensive research, leading to development in the inspection, non-destructive testing, monitoring and structural analysis of constructions. However, the teaching of this topic has not received the same attention. The analysis of existing buildings creates challenges given the complexity of their geometry, the variability in the properties of traditional materials, the different construction techniques, the absence of knowledge about existing damage, and how certain actions affect buildings throughout their lifetime (Roca 2007). These challenges mean that existing buildings are subject to a number of difficulties in diagnosis and intervention, which in some cases limit the application of the regulatory requirements and existing guidelines in the general area of construction. Therefore, understanding, analysis and repair of buildings constitute one of the most important challenges for modern engineers (Lourenço et al. 2008).

In many countries, it is usual to act without devoting adequate resources to the study of why a construction requires intervention, mainly due to economic and time pressure. In fact, there have been aggressive interventions, causing a reduction in the value of the buildings, especially in the case of historically significant ones, or inappropriate 
interventions that do not solve the problem. It is therefore necessary to make some recommendations to ensure implementation of rational analysis and rehabilitation methods.

The building rehabilitation and maintenance market is one of the most important economic sectors in construction, especially in the most developed societies. For instance, in Europe, in 2010, rehabilitation and maintenance was a major market, accounting for $28 \%$ of construction output with a value of $332 \cdot 10^{6} €$ (FIEC 2010), and in the USA, this sector also accounts for an important fraction of the construction market. In addition, there are many other factors which indicate that the rehabilitation market has high growth potential in many countries: the growing social awareness that preservation and enjoyment of the building heritage has acquired, the favorable prospects offered in certain areas by the cultural sector as an engine for activity (Cultural Tourism), the progressive ageing of existing housing, etc. Moreover, the rehabilitation sector is a key topic in terms of sustainable urban growth: promoting lower energy consumption (in contrast with demolition and new work), consuming less material than new construction work, etc.

\section{Focus of the guideline course}

In construction rehabilitation there is wide variety of policies with extreme situations. Preservation laws and regulations vary significantly from one country to another, thus in some European countries the preservation laws are fairly rigid, while other countries do not directly consider rehabilitation policy. The same occurs in the legal jurisdiction for scope of practice in this area. For example, in the United States the jurisdiction over many of the items under consideration is controlled by Architects not Civil Engineers, 
while in the UK, among the accreditation schemes developed, it is the Conservation Accreditation Register for Engineers (CARE) that has jurisdiction.

To design a guideline course, first of all, we should ask ourselves some basic questions: When should a structure be rehabilitated? What procedure should be adopted during the inspection? Do students have previous knowledge about the behavior of traditional materials and about newly applied ones? What is more, we could add another question to all of these: Why? The civil engineer, at the design level (Dally et al. 2012), should be able to adopt an approach when answering these questions.

On the other hand, we must pay attention to highlighted historic buildings, whose need for rehabilitation and maintenance is especially significant because their potential failure has important consequences (from technical, cultural and economical points of view). In this type of construction the provision of rehabilitation protocols to be adopted must be carefully considered. Nevertheless, there are existing buildings, which are not unique from the cultural point of view, but which must be rehabilitated, sometimes simply due to changes in functionality or habitability. Their lesser singularity does not preclude requiring similar exhaustive analysis. Besides, this day-to-day rehabilitation market contributes significantly to the economy of the construction sector. In the authors' opinion, both types of buildings must be targeted by the educational proposal.

All these circumstances result in the need for specific training of engineers dedicated to this area, including Civil Engineers. Lombillo et al. (2013) analyzed the current dedication worldwide to construction rehabilitation within the Faculties or Schools of Civil Engineering. As was already mentioned, although rehabilitation and maintenance of constructions is one of the most important sectors within construction, and that it has an increasing growth potential in many countries, construction rehabilitation is 
generally insufficiently addressed as a single course in the faculties of Civil Engineering.

As a result, and based on the previously mentioned research, we consider that the study of this course should be at least optional in Civil Engineering at the bachelor degree level due to the increasing demand for rehabilitation of existing buildings. For this reason and considering the varying practices in different countries, this article proposes an international guideline course in construction rehabilitation with the aim of collaborating, creating joint strategies for action and relationships among university colleagues.

\section{NEED FOR CONSTRUCTION REHABILITATION COURSE}

This article culminates in the selection of topics integrating all the information generated throughout the research. However, as a previous justification, in the following section, we introduce some of the topics considered important in order to complete the construction rehabilitation guideline course.

Due to the previously mentioned challenges of analyzing existing buildings, we have to adopt a general methodology through consensus. As an example, Figure 1 illustrates a rational analysis procedure (Lombillo 2010).

Within these phases, previous knowledge is fundamental in choosing the most suitable techniques and materials applicable in later stages of Design/Project and Work (Binda et al. 2009). Moreover, carrying out these preliminary studies will lead to a reduction both in overall costs of the intervention and in the working times (Lourenco et al. 2008), since these phases of previous study (phases 1-3) can limit the uncertainty in the intervention. 
Therefore, we should base the rehabilitation process on a precise preliminary investigation (Binda et al. 2008), in order to document the current state of the construction. So, we should approach the rehabilitation process from a multidisciplinary point of view, considering the previously mentioned complementary aspects including: the historical evolution of the buildings, geometry, cracking patterns, characteristics of the materials, construction technology, potential failure mechanisms, etc. (Penazzi et al. 2000). In this regard, collaboration is essential among architects, engineers, chemists, restorers, historians, archaeologists, etc. In this sense, Binda et al. (2000) suggest, in relation to studies carried out for the rehabilitation of the "Torrazzo" of Cremona (Italy): "The multidisciplinary nature of the working method is the fundamental key to the successful development of the investigation".

At this point, we have sufficient motivation to ask the question: What construction types should we train Civil Engineers in? The following paragraphs give details about them.

Most historical monuments are masonry buildings, as are many residential buildings, and there is also an extensive number of civil engineering structures, bridges, retaining walls and reinforcement in highways, etc. In Europe alone, according to the International Council on Monuments and Sites (ICOMOS), there are 500,000 registered monuments: $20 \%$ have structural problems, of which $40 \%$ may be categorized as masonry constructions/buildings, which implies 40,000 possible interventions on existing buildings, to which we could add a number of civil engineering structures (infrastructures, bridges, etc.) (Garmendia 2010). Therefore, the creation of a teaching module dealing with rehabilitation of masonry structures is necessary in Civil Engineering degrees. However, research and advanced studies of historical masonry structures have progressed slowly in comparison to work on other structures made of 
concrete or steel materials, leading to a notable absence of knowledge and experience in this field.

A large part of the world's population lives or works in earthen buildings (Houben and Guillaud 1989). As a reference, as of March 2012, of the 563 cultural heritage sites that the World Heritage Committee has inscribed in its list, 96 (17\%) are completely or partially built of earth (Unesco 2012). We can find earthen constructions practically all over the world, with a special importance in developing countries, where they still use other building materials limitedly and traditional construction is still common. In any case, earthen construction is more sensitive than its modern counterpart, as it is more vulnerable to external agents. These considerations highlight the need to take into account effective diagnostic techniques to help assess the state of conservation of earthen architecture, and adopt intervention methods in order to preserve these constructions.

In the United States, an important part of the population lives in houses constructed almost entirely of wood, but only a small minority of students entering graduate programs in structural engineering and materials science choose to specialize in timber (Langenbach 2010). In Germany for example, only 14\% of all single family houses and negligible numbers of other buildings are constructed of timber (Betz 2006). In large parts of China, timber used to be in common use for buildings. Today, wood construction has been almost entirely displaced by concrete, even in smaller settlements.

Traditional constructions, either common buildings or historic and monuments, have used timber extensively for structures supporting floors and roof trusses. At worldwide level there are lots of residential, religious or military timber structures. As an example, Figure 2 shows a wooden support in a historic building in a rural part of Spain. In 
addition, in the case of common buildings, during a long period that peaked in the $1970 \mathrm{~s}$ and 1980s, timber floors and roof structures were widely substituted as a whole with new materials and construction techniques. In some cases, however, negative consequences, even including structural collapse, have occurred especially when the newly constructed structure underwent ground shaking due to earthquakes. In this sense, we must establish efficient assessment methods for traditional timber-frame buildings, able to identify and quantify their vulnerability and provide advice for strengthening strategies, thus minimizing alterations and loss of value and significance (Tsai and D'Ayala 2011). To sum up, the reintroduction of engineering classes that focus on the science and structural engineering of buildings with timber is urgent (Langenbach 2010), and especially teaching aimed at the rehabilitation of existing wooden structures.

There are more than 160 million buildings in Europe, $80 \%$ of which are structures made with reinforced concrete or unreinforced masonry, and over $25 \%$ are pre-1960 according to Housing Statistics in the European Union, 2004 (Boverket and MMR 2005). We will have to restore, rehabilitate, partially reconstruct or demolish a large number of these buildings, built during the construction boom in the 1950s and 1960s. A considerable percentage of the housing stock is beginning to need interventions, some of which are structural. This scenario changes in every country and is directly affected by environment, local policies and industrial activity. However, any such changes are merely quantitative; the overall picture remains quite similar for all European countries. Iron-based alloy structures are fundamental in construction and rehabilitation of buildings. One of the factors to be considered is kinetic attack, given that most structures are exposed to the weather, under different types of atmospheres, the most aggressive being industrial marine conditions. Therefore, if we choose a specific type of 
steel for a structural rehabilitation application, we must take into account many variables (Lombillo et al. 2011; Thomas et al. 2010), the most influential of which are chemical composition and microstructure. We should highlight that we could avoid numerous pathological processes, such as the effects of certain types of corrosion, merely by applying basic materials science concepts. In this particular case, Figure 3 shows galvanic corrosion between the base of a galvanized steel column and carbon steel bolts. If we take into consideration the Uhlig report, the construction sector could save approximately $20 \%$ of the costs caused by corrosion if the correct anticorrosion measures were taken.

Finally, among other topics, there is a need to provide a minimal knowledge base in the seismic behavior of existing buildings in order to minimize the damaging effects of earthquakes in constructions.

\section{METHOD OF GUIDELINE COURSE DEVELOPMENT}

One of the challenges is to sufficiently unify the criteria of an optional course with great impact on society, training our students in the basics, with a proposal of a common course and focus in all the Civil Engineering degrees worldwide. Logically, we should consider the approach as a general guide, since each university should pay special attention to the topics that are most common in its constructive practices, taking into account the regional and national reality.

The course goal is to motivate the undergraduate Civil Engineering students to appreciate the importance of doing a good job in terms of: Study of existing information, inspection-analysis, diagnosis, intervention, control and monitoring, and 
maintenance of existing buildings, taking into account the different kinds of structures (both old buildings and new ones).

Figure 4 illustrates the guideline course development methodology, based on proposing a table of minimum contents for a single course on Construction Rehabilitation in Civil Engineering at the bachelor degree level after processing the data from a number of questionnaires received from teachers involved in Construction Rehabilitation teaching worldwide, as well as on the authors' own experience. Following consultation with several experts, we prepared a guideline course. This involved the following stages:

\section{Survey}

Lombillo et al. (2013) found that, with the exception of the rehabilitation of concrete structures, the issues within the knowledge area of Construction Rehabilitation are dealt with more completely at post-graduate level than at the bachelor degree level (Figure 5). In addition, not all the topics covered in the survey are taught with the same preference. At the bachelor degree level, there is less content related to old buildings compared to modern ones. Thus, explanation of general and methodological concepts, examples of pathology reports and previous studies, and rehabilitation of concrete structures are the most commonly discussed topics at the bachelor degree level. This is confirmed by more than $70 \%$ of the surveys. In postgraduate study, as well as some of the previously mentioned, over $70 \%$ of respondents explain examples of intervention in old buildings. In contrast, the least studied topics are rehabilitation of earthworks $(17 \%$ in the bachelor degree and $8 \%$ in postgraduate), strategies for monitoring and control of buildings $(37 \%$ and $31 \%$ respectively), concepts about the history of construction (37\% and $46 \%)$, aspects related to intervention in foundations of buildings, whether old or modern, and the rehabilitation of steel and cast iron structures (34\% bachelor's degree and $46 \%$ 
postgraduate). Therefore, in view of these results, we propose more evenly balancing the intensity of dealing with different topics suitable for inclusion in the Construction Rehabilitation course, as there was less dedication to content related to old buildings than to modern ones. Furthermore, the above reference listed a series of contents, complementary to those included in the questionnaire, which part of the respondents reported dealing with in their subjects. In this sense, due to the repetition found, we should highlight the following: Assessment of existing structures (in-situ inspection, inlaboratory investigation techniques and monitoring), seismic behavior of existing buildings, and technology for rehabilitation of non-structural anomalies in buildings (humidity problems, roofs and facades). We also took all these contents into account to propose a comprehensive guideline for the Construction Rehabilitation course.

We grouped the topics in eight large blocks and we assigned teaching hours (Table 1). As can be seen, face-to-face teaching accounts for a total of 60 hours.

We considered it necessary to include a block of practical contents consisting in visits to buildings under rehabilitation, workshops with professionals involved in rehabilitation of buildings and practicals in Laboratories. The aim of this practical block is to introduce the students to professional responsibilities and investigation.

\section{Expert review}

Among the colleagues who responded to the questionnaire, we selected three internationally renowned professors in the Construction Rehabilitation area to provide their opinions on the preliminary guideline course which we had elaborated.

Table 2 shows, in the first three columns, the proposed teaching content and the preassigned teaching hours. 
The next six columns integrate the experts' opinions related to the relevance of each of the topics (greater, medium or minor) and the time they consider necessary to dedicate to each topic (more, the same or less)."Minor relevance" means that they could be important for other courses but, here, the students should already know them. The column with "less time" does not represent a low appreciation of the item but, in some cases, exactly the opposite; for example "foundations" is quite complex and long, as well as "calculation" or "history of construction" and cannot be deeply considered in this course, so they must remain simple "pointers" to other courses or publications.

To facilitate the readers' interpretation of the table, for example, in the case of the first aspect "I.1.- General concepts: Building Pathology and Rehabilitation" one of the three experts considered it to have great relevance and two medium relevance, and all three considered the pre-assigned teaching hours to be suitable.

Based on the most relevant conclusions extracted from the experts' opinions, the initial guideline was rewritten. Fundamentally, in relation to the pre-assigned times, we reduced the dedication to topics such as "I.2.- Notions about the history of construction / historic construction systems", "III.1.- Foundations" and "V.1.- Effects of earthquakes on constructions". In contrast, we increased the dedication to the following topics: "I.3.General methodology", "V.2.- Methodologies for the seismic safety assessment of constructions" and "V.3.- Seismic strengthening solutions". We would like to highlight that none of the topics was eliminated due to the opinions of the experts.

\section{PROPOSED CONSTRUCTION REHABILITATION GUIDELINE COURSE}

\section{Content}


We took precautions when unifying the responses due to the priority that each experience (lecturer/university, region or country) gives to a specific aspect. In this section a sequential program directed to students of Civil Engineering at the bachelor degree level is proposed with minimum contents that could provide a starting point in any country in the world.

\section{I.- General Notions $(6.0$ h).}

I.1.- General concepts $(1.0$ h): Building Pathology and Rehabilitation. Criteria and principles for conservation of existing buildings.

I.2.- Notions about history of construction, construction systems and construction details $(1.5 \mathrm{~h})$.

I.3.- General methodology $(2.5 h)$ : Study of the existing information, Diagnosis, Design, Execution and Control of work, and Maintenance.

\section{I.4.- Provisional scaffolding $(1.0 \mathrm{~h})$.}

A topic related to the appropriate codes, standards, regulations, government requirements and project funding sources may be considered in the course.

II.- Assessment of Existing Structures $(12.0 \mathrm{~h})$.

II.1.- The importance of identifying the structural system $(1.0 \mathrm{~h})$.

II.2.- In-situ inspection: Non or Minor Destructive Techniques (3.0 h): Techniques applied to masonry structures, timber structures, concrete structures and structures of iron-based alloys.

II.3.- In-laboratory investigation techniques $(2.0 \mathrm{~h})$ : Laboratory tests on samples extracted from homogeneous material. Laboratory tests on heterogeneous material.

II.4.- Monitoring $(1.5$ h): Sensor types. Typologies of acquisition systems and remote transmission of data. 
II.5.- Introduction to the analysis of the structural safety of existing constructions (1.5 h): Past-performance (analysis of the historic behavior of constructions). Integration of experimental and analytical perspectives in the determination of construction safety (structural reliability).

II.6.- Examples of pathology reports and previous studies of building rehabilitation $(3.0 \mathrm{~h})$.

III.- Old building rehabilitation: Symptoms, causes and intervention techniques $(14.0 \mathrm{~h})$.

III.1.- Foundations $(2.0$ h): Typologies of foundations. Origin of failure in foundations. Symptoms of failure in foundations, causes and applicable therapy. Actuations on the soil.

III.2.- Masonry structures: Brickwork or stone bearing walls (and columns) (3.0 h): Notions about materials: bricks, stones, mortars, masonries, special materials adopted for rehabilitating or strengthening structures. Mechanics of masonry in compression, tension, shear, out-of-plane bending. Structural-type pathological processes and applicable therapy.

III.3.- Masonry structures: Arches, vaults and domes $(1.0 \quad h)$ : Historic development of mechanics of arches vaults and domes. Structural-type pathological processes and applicable therapy.

III.4.- Timber structures $(3.0 \mathrm{~h})$ : Wood as a construction material. Structural-type pathological processes and applicable therapy. Pathological processes due to biotic damage and applicable therapy. Wood protection.

III.5.- Earthen construction rehabilitation $(1.0 h)$ : Historic rammed-earth construction worldwide distribution. Notions about materials: Rammed earth and 
mud brick (wattle and daub). Classical testing and modeling. Rammed-earth construction: Typologies, failure and repair. Mud brick (wattle and daub) construction: Typologies, failure and repair.

III.6.- Examples of intervention $(4.0 \mathrm{~h})$.

\section{IV.- Modern building rehabilitation: Symptoms, causes and intervention} techniques $(10.0 \mathrm{~h})$.

IV.1.- Concrete structures $(4.0$ h): Failure statistics. Particularities of earlytwentieth-century reinforced concrete construction. Durability study methodology in reinforced concrete buildings (Documentation, field work, laboratory tests, diagnosis and applicable therapy). Pathological processes in structural concrete: Physical or chemical damage and failure due to insufficient mechanical strength. Applicable therapy.

IV.2.- Structures of iron-based alloys (steel and cast iron) $(3.0 \mathrm{~h})$ : Historical introduction to metallic structures. Material used in steel structures - historical review. Mechanical properties of cast iron, mild iron and steel in existing structures. Causes and analysis of steel structural failures. Pathological processes in metallic structures related to design. Introduction to basic methods of reinforcing steel structures. Corrosion damage and its repair.

IV.3.- Examples of intervention $(3.0 h)$.

V.- Seismic behavior of existing buildings $(6.0 \mathrm{~h})$.

V.1.- General concepts $(1.0 h)$ : Seismological engineering. Effects of earthquakes on constructions: Pathological processes from recent earthquakes.

V.2.- Methodologies for seismic safety assessment of constructions $(2.5 \mathrm{~h})$. 
V.3.- Seismic strengthening solutions $(2.5 h)$ : Seismic strengthening solutions for old masonry buildings. Seismic strengthening solutions for reinforced concrete buildings.

VI.- Technology for rehabilitation of non-structural anomalies in buildings $(5.0 \mathrm{~h})$. VI.1.- Humidity problems $(2.0 \mathrm{~h})$. Concept of damp. Analysis of types of damp. Problems that become apparent. Capillary damp. Damage produced. Applicable therapy. Condensation and filtration damp. Damage produced. Applicable therapy.

VI.2.- External building elements (roofs and facades) $(3.0 \mathrm{~h})$.

\section{VII.- Strategies for maintenance and control $(3.0 \mathrm{~h})$.}

VII.1.- Building control and monitoring strategies $(1.5 \mathrm{~h})$. Control program and monitoring during the execution of the intervention.

VII.2.- Building maintenance strategies $(1.5$ h). Preventive and corrective strategies.

VIII.- Practical $(4.0$ h).

Visits to buildings under rehabilitation and/or Workshops with other students and professionals involved in rehabilitation of buildings and/or Practical work in

\section{Laboratory.}

\section{Teaching modes}

Table 3 shows, for the different blocks of topics, the face-to-face teaching hours depending on the type of teaching, and the hours of student dedication outside class related to the type of teaching.

Table 4 proposes possibilities for the different forms of face-to-face teaching and the distinct methods of autonomous learning entailed by the subject. We also indicate the 
number of hours related to each form of teaching-learning, along with the percentage of each type out of the total for the subject.

\section{Learning outcomes}

Two main learning outcomes have been identified. First, the Civil Engineering students who take this optional course will improve their analytical, synthetic, critical and logical thinking. The students will both enhance their ability to recognize, analyze and diagnose problems that commonly appear in existing buildings, taking into account the different kinds of structures (both old buildings and new ones), and also increase their ability to write reports on building pathology.

Second, the students will improve their knowledge in aspects necessary to perform functions of consulting, design, project preparation, construction, maintenance and preservation of buildings. They will thus augment their ability to propose solutions for rehabilitation of defects present in different scenarios in constructions.

\section{Assessment criterion}

Table 5 proposes a possible form of evaluation of the student, coherent with the autonomous learning methods promoted by the subject.

\section{CONCLUSIONS}

Given that we live in an increasingly global world, the approach in the course of Construction Rehabilitation aims to train students in the same basic elements in all Civil Engineering studies worldwide. However, the course proposed in this paper should be considered as a general guide, in such a way that each university must pay special attention to the topics that are most common within its own area's construction practices, considering both the regional and national levels. Furthermore, each 
university should review the course's contents to adapt them, in every moment, to the needs of the industrial sector, and society in general.

After an extensive study in which university professors from carefully selected countries have participated, we have proposed topics that should be considered within a Construction Rehabilitation course. Moreover, we have also proposed that this course should involve $60 \%$ of autonomous work by students, of which the so-called individual reflection, based on the assimilation of meticulously prepared case studies, should have particular relevance. The other $40 \%$ would be traditional lectures with explanations of content by teachers, including demonstrations. In this way, we wish to highlight the importance of previous study to achieve appropriate diagnosis, a key phase, in the authors' opinion, in any rehabilitation process.

Finally, due to the time constraints of the course and the magnitude of the topics included, certain contents could be more suitable for inclusion in other courses, for example, the topic of rehabilitation of non-structural anomalies in buildings, the highly complex topic of analysis of the structural safety of existing constructions or the block devoted to seismic behavior of existing buildings.

As a final comment, it is necessary to recognize that it is important to survey both business and practicing engineers' perspectives on educational needs in Construction Rehabilitation before further developing this course in the University. Therefore, with the objective of polishing the guideline course based on practical and social demands, the survey of professional opinion should be the next step to develop in a future study.

\section{ACKNOWLEDGMENTS}


The authors wish to thank all those colleagues from around the world who devoted some of their precious time to answer our questions and share their experience in the subject, without whom this study would not have been possible.

\section{REFERENCES}

Betz, J. (2006). “Thick Cross-laminated Solid Wood Panels in Europe". Faculty of Forestry Report. University of British Columbia.

Binda, L., Anzani, A., and Cardani, G. (2009). "Methodologies for the evaluation of seismic vulnerability of complex masonry buildings: case histories in the historic centre of Sulmona". Proc.11th Int. Conf. on Structural Repairs and Maintenance of Heritage Architecture, Wessex Institute of Technology, Ashurst, Southampton, UK, 395-405.

Binda, L., Lualdi, M., and Saisi, A. (2008). "Investigation strategies for the diagnosis of historic structures: on-site tests on Avio Castle, Italy, and Pisece Castle, Slovenia”. Can. J. Civ. Eng., $35,555-566$.

Binda, L., Tongini-Folli, R., and Mirabella-Roberti, G. (2000). "Survey and investigation for the diagnosis of damaged masonry structures: the Torrazzo of Cremona". Proc. 12th Int. Brick/Block Masonry Conf., Madrid, Spain, 237-257.

Boverket and MMR (2005). "Housing Statistics in the European Union 2004". National Boards of Housing, building and Planning, Sweden (Boverket) and the Ministry of Regional Development of the Czech Republic (MMR). Boverket Pubikatios service, Karlskrona, Sweden.

Dally, S.R., Adams, R.S., and Border, G.M. (2012). "What does it mean to design? A qualitative investigation of design professionals' experiences". Journal of Eng. Education, 101(4), 28-33. 
FIEC (2010). "Construction activity in Europe (2010) by market sectors". European Construction Industry Federation. $\quad<$ http://www.fiec.eu/Content/Default.asp?PageID=31 $>$ (March 20, 2012).

Garmendia, L. (2010). "Rehabilitation of masonry arches by a compatible and minimally invasive strengthening system”. Ph.D. thesis. University of the Basque Country, Bilbao, Spain. Houben, H., and Guillaud, H. (1989). "Earth construction. A comprehensive guide". Editions Parenthèses, Marseille.

Langenbach, R. (2010). "Better than steel? The use of timber for large and tall buildings from ancient times until the present". Structures and Architecture - Proc. Ist Int. Conf. on Structures and Architecture, ICSA 2010, 355-366.

Lombillo, I., Biezma, M.V., and Villegas, L. (2013). "Is sufficient attention given worldwide to Construction rehabilitation in Civil Engineering Schools?". Technics Technologies Education Management-TTEM, Vol. 8, nº 2, pp. 729-739.

Lombillo, I., Thomas, C., Villegas, L., Polanco, J.A., Setién, J., and Biezma, M.V. (2011). "Mechanical behavior of anchorages for reinforcing marine stone structures subjected to sea waves". J. Materials in Civ. Eng., 23(5), 682-691.

Lombillo, I. (2010). "Investigación teórico - experimental sobre ensayos ligeramente destructivos (MDT) utilizados para la caracterización mecánica in situ de Estructuras de Fábrica del Patrimonio Construido". Ph.D. thesis. University of Cantabria, Santander, Spain.

Lourenco, P.B., Ramos, L.F., Vasconcelos, G., and Peña, F. (2008). "Monastery of Salzedas (Portugal): Intervention in the cloister and information management". Proc. Int. Conf. on Structural Analysis of Historic Construction. Taylor \& Francis Group, London, UK, 95-108.

Penazzi, D., Valluzzi, M.R., Cardani, G., Binda, L., Baronio, G., and Modena, C. (2000). "Behaviour of historic masonry buildings in seismic areas: lessons learned from the UmbriaMarche earthquake". Proc. 12th Int. Brick-Block Masonry Conference, Madrid. 
Roca, P. (2007). “Aplicación de técnicas experimentales y numéricas al estudio del patrimonio arquitectónico". Proc. Conf. on Metodologías no destructivas aplicables a la rehabilitación del patrimonio construido, Universidad de Cantabria, Santander, Spain, 53-70.

Thomas, C., Lombillo, I., Polanco, J.A., Villegas, L., Setién, J., and Biezma, M.V. (2010). "Polymeric and cementitious mortars for the reconstruction of natural stone structures exposed to marine environments." Composites, Part B, 41(8), 663-672.

Tsai, P.H., and D'Ayala, D. (2011). "Performance-based seismic assessment method for Taiwanese historic Dieh-Dou timber structures". Earthquake engineering and structural dynamics, 40, 709-729.

Unesco (2012). "World Heritage List". UNESCO, $<$ http://whc.unesco.org/en/list> $>$ (March 20, 2012). 
Journal of Performance of Constructed Facilities. Submitted July 2, 2013; accepted November 11, 2013; posted ahead of print November 13, 2013. doi:10.1061/(ASCE)CF.1943-5509.0000540

\section{FIGURE CAPTIONS}

Figure 1: Methodological process proposed for intervention in existing constructions.

Figure 2: Wooden support structure in the Hotel "Palacio de Casafuerte" of Zarratón (Spain).

Figure 3: Galvanic corrosion between the base of a galvanized steel column and carbon steel bolts.

Figure 4: Guideline course development methodology.

Figure 5: Radial diagram of the teaching intensity in different topics related to construction rehabilitation worldwide (per unit). 


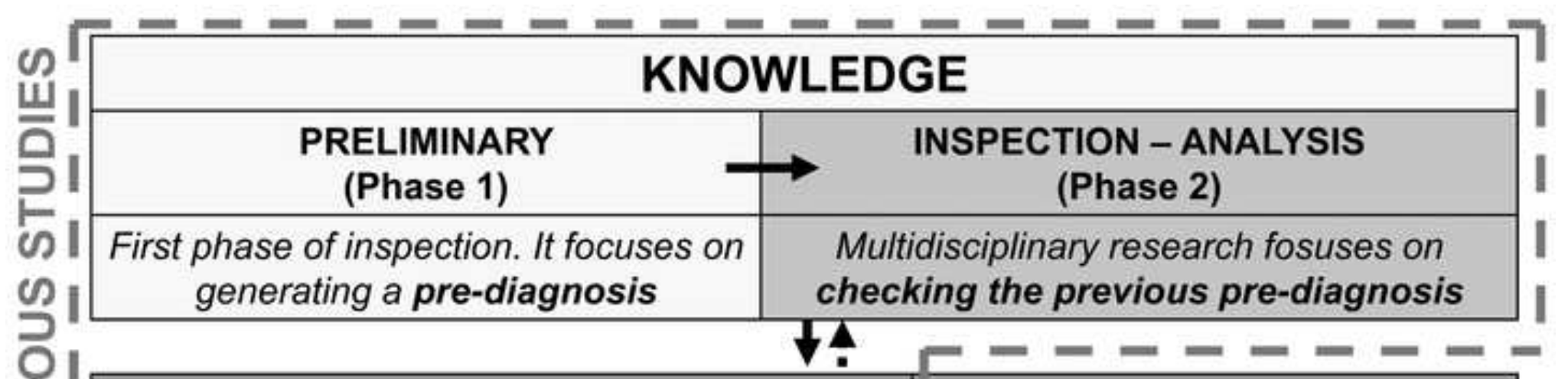

\section{DIAGNOSIS-SYNTHESIS (Phase 3) REFLECTION AND}

$\stackrel{\alpha}{\alpha}$ This phase focuses on the synthesis of the $\longrightarrow$ DECISION TAKING

Q. information generated

(Phase 4)

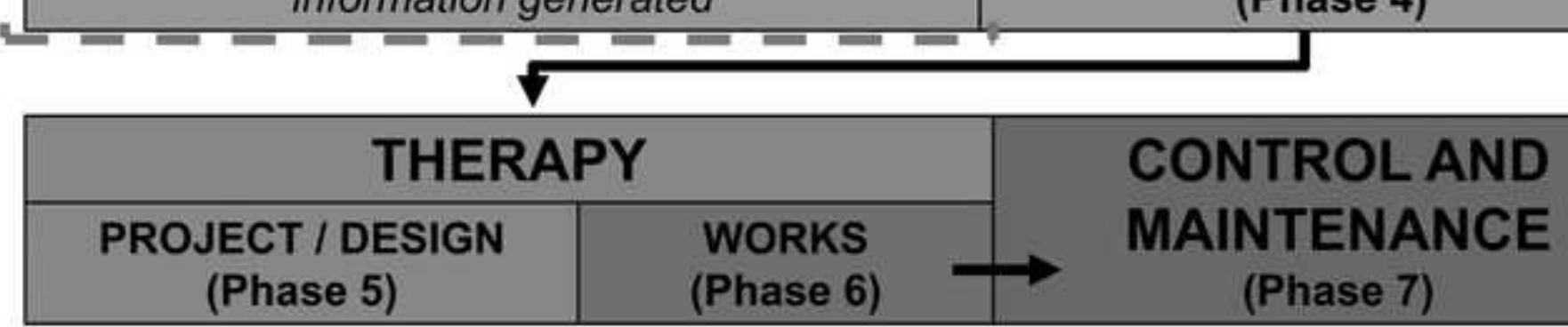




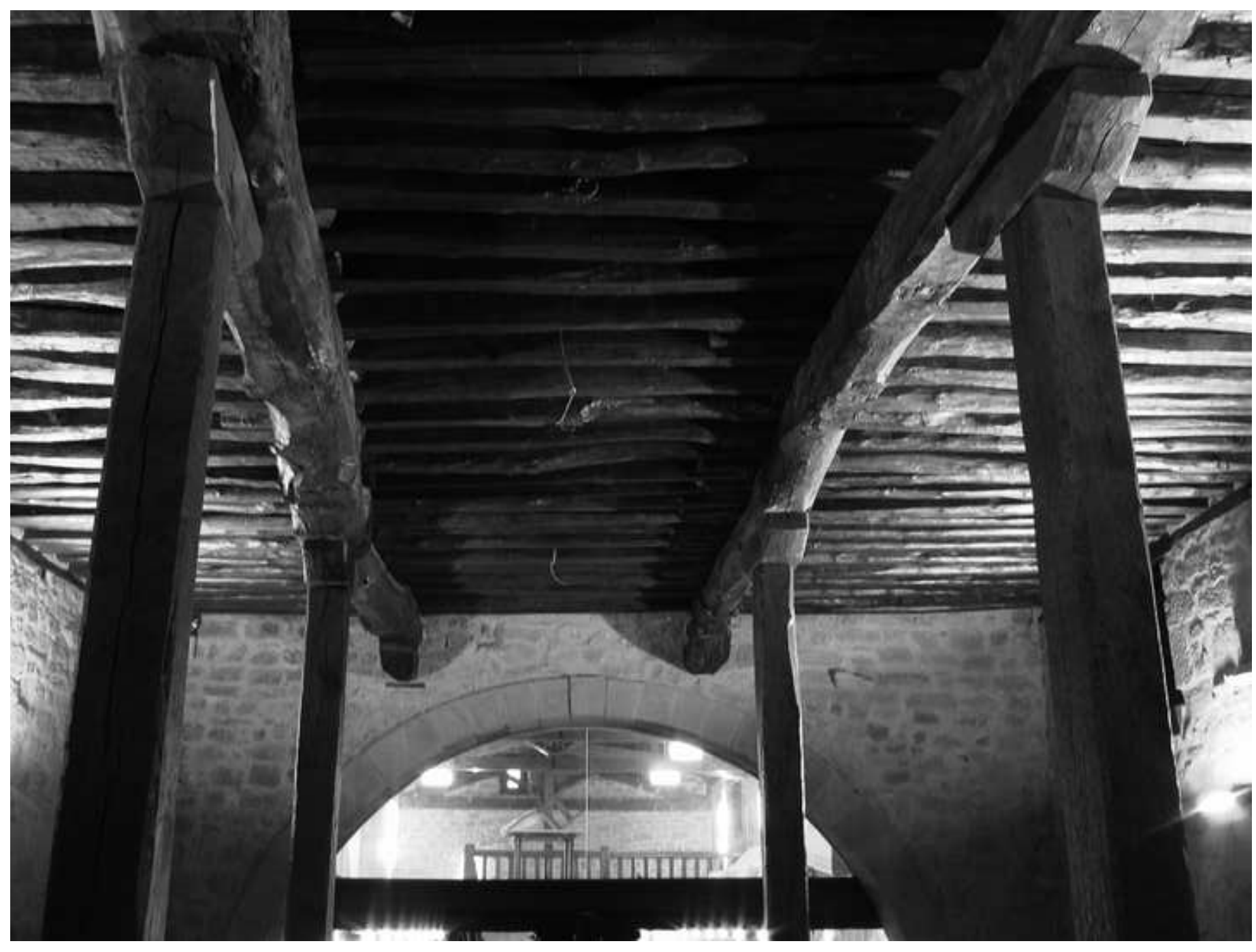




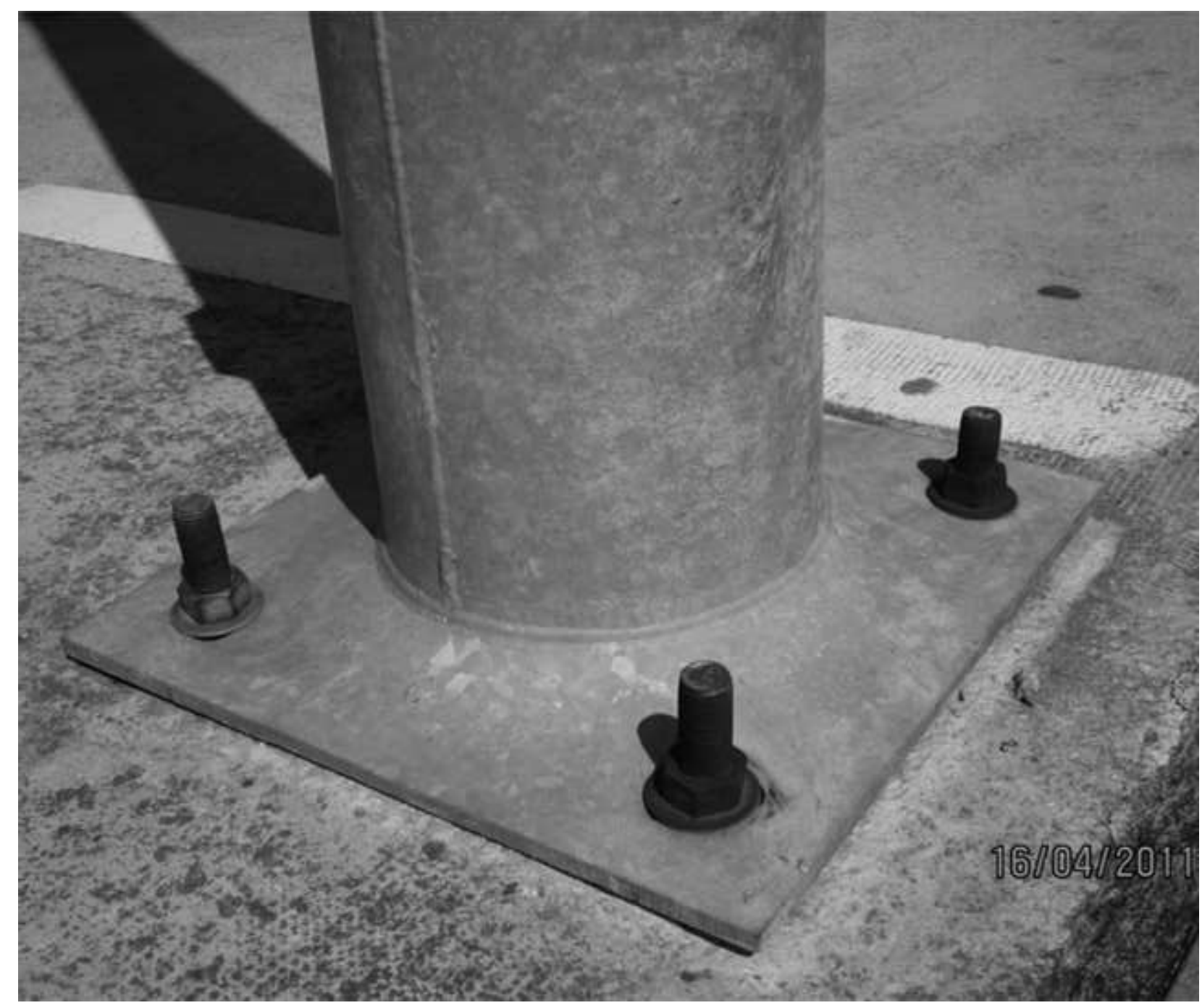



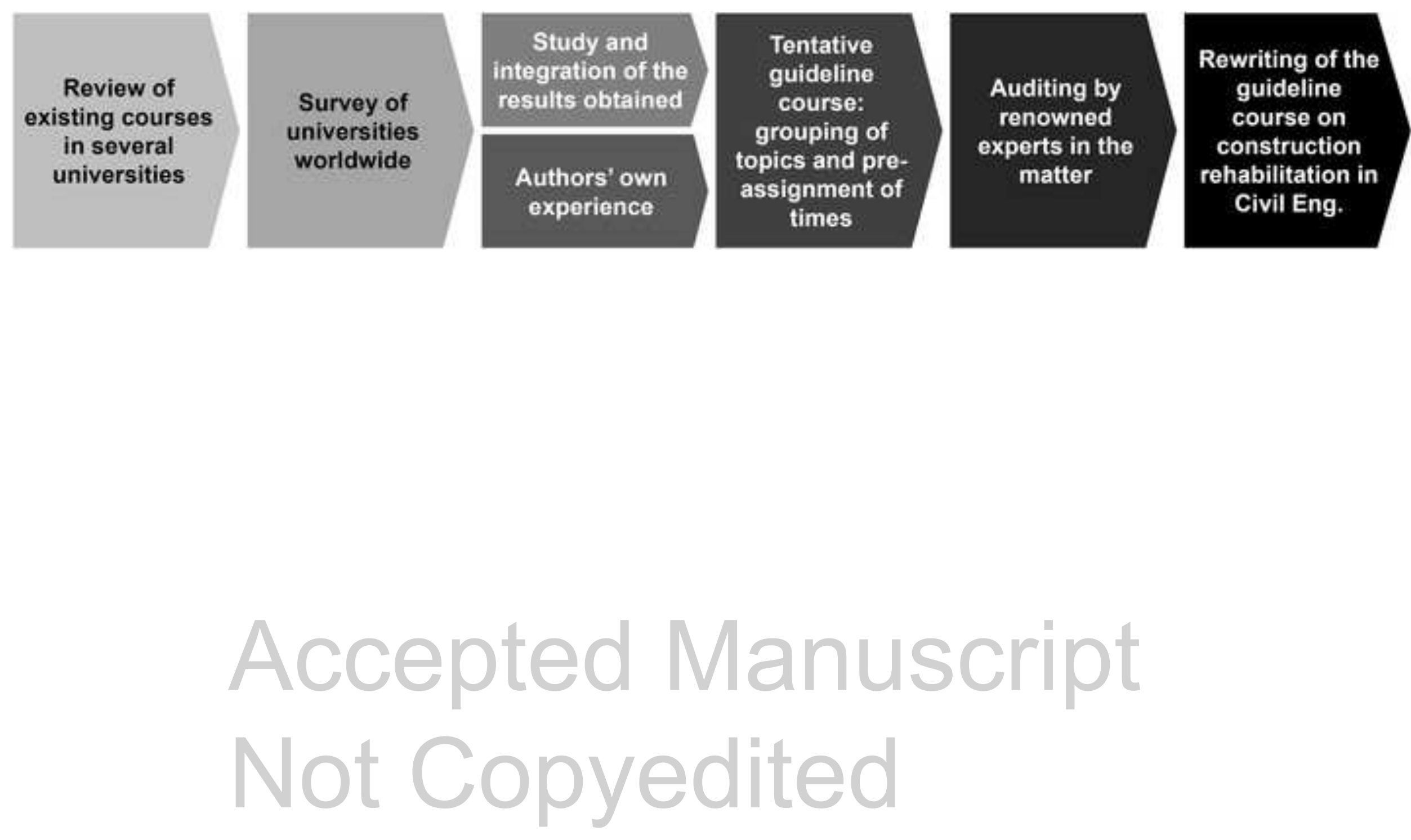

Copyright 2013 by the American Society of Civil Engineers 
Journal of Performance of Constructed Facilities. Submitted July 2, 2013; accepted November 11, 2013; posted ahead of print November 13, 2013. doi:10.1061/(ASCE)CF.1943-5509.0000540

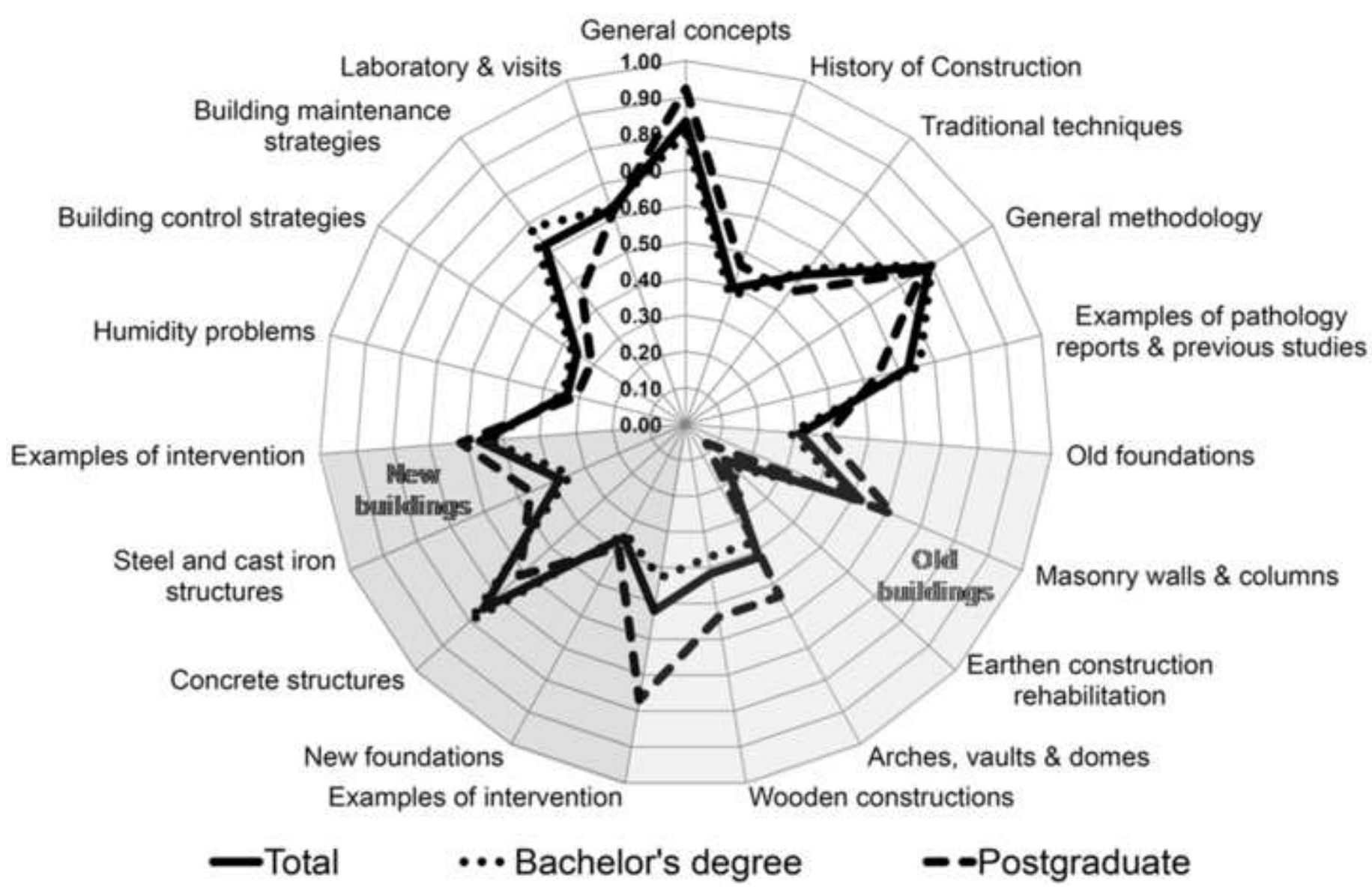


Table 1: Proposal of 8 topic areas within the course and pre-assignment of teaching hours for face-to-face classes

\begin{tabular}{|l|c|}
\hline \multicolumn{1}{|c|}{ Topic block } & Pre-assigned teaching hours \\
\hline I.- General Notions & 6.0 \\
\hline II.- Assessment of Existing Structures & 12.0 \\
\hline III.- Old building rehabilitation: Symptoms, causes and intervention techniques & 15.0 \\
\hline IV.- Modern building rehabilitation: Symptoms, causes and intervention techniques & 10.0 \\
\hline V.- Seismic behavior of historic buildings & 5.0 \\
\hline VI.- Technology for rehabilitation of non-structural anomalies in buildings & 5.0 \\
\hline VII.- Strategies for maintenance and control & 3.0 \\
\hline VIII.- Practical work & 4.0 \\
\hline
\end{tabular}

Accepted Manuscript Not Copyedited 
Table 2: Topics proposed for inclusion in the course "Construction Rehabilitation". Initially pre-assigned times and expert opinion (the topics shaded underwent variation due to the experts' opinions).

\begin{tabular}{|c|c|c|c|c|c|c|c|c|}
\hline \multirow{2}{*}{ Topics } & \multirow{2}{*}{ Brief description } & \multirow{2}{*}{$\begin{array}{c}\text { Pre-assigned } \\
\text { Time (h) }\end{array}$} & \multicolumn{3}{|c|}{ Relevance } & \multicolumn{3}{|c|}{ Time } \\
\hline & & & Greater & Medium & Minor & More & The same & Less \\
\hline \multirow{4}{*}{ I.- General notions } & \begin{tabular}{|l|} 
I.1.- General concepts: Building \\
Pathology and Rehabilitation \\
\end{tabular} & 1.0 & 1 & 2 & 0 & 0 & 3 & 0 \\
\hline & $\begin{array}{l}\text { I.2.- Notions about history of } \\
\text { construction / historic construction } \\
\text { systems }\end{array}$ & 3.0 & 1 & 1 & 1 & 0 & 2 & 1 \\
\hline & I.3.- General methodology & 1.0 & 2 & 1 & 0 & 2 & 1 & 0 \\
\hline & I.4.- Provisional scaffolding & 1.0 & 1 & 1 & 1 & 0 & 2 & 1 \\
\hline \multirow{6}{*}{$\begin{array}{l}\text { II.- Assessment of } \\
\text { Existing Structures }\end{array}$} & $\begin{array}{l}\text { II.1.- The importance of identifying } \\
\text { the structural system }\end{array}$ & 1.0 & 3 & 0 & 0 & 1 & 2 & 0 \\
\hline & II.2.- In-situ inspection & 3.0 & 3 & 0 & 0 & 0 & 3 & 0 \\
\hline & $\begin{array}{l}\text { II.3.- In-laboratory investigation } \\
\text { techniques. }\end{array}$ & 2.0 & 2 & 1 & 0 & 0 & 3 & 0 \\
\hline & II.4.- Monitoring & 1.5 & 3 & 0 & 0 & 0 & 3 & 0 \\
\hline & $\begin{array}{l}\text { II.5.- Introduction to calculation } \\
\text { techniques }\end{array}$ & 1.5 & 2 & 1 & 0 & 0 & 3 & 0 \\
\hline & $\begin{array}{l}\text { II.6.- Examples of pathology reports } \\
\text { and previous studies of building } \\
\text { rehabilitation }\end{array}$ & 3.0 & 2 & 1 & 0 & 0 & 3 & 0 \\
\hline \multirow{6}{*}{$\begin{array}{l}\text { III.- Old building } \\
\text { rehabilitation }\end{array}$} & III.1.- Foundations & 3.0 & 1 & 2 & 0 & 0 & 2 & 1 \\
\hline & $\begin{array}{l}\text { III.2.- Masonry structures: Brickwork } \\
\text { or stone bearing walls (and columns). }\end{array}$ & 3.0 & 2 & 1 & 0 & 0 & 3 & 0 \\
\hline & $\begin{array}{l}\text { III.3.- Masonry structures: Arches. } \\
\text { vaults and domes }\end{array}$ & 1.0 & 1 & 2 & 0 & 0 & 3 & 0 \\
\hline & III.4.- Timber structures & 3.0 & 2 & 1 & 0 & 0 & 3 & 0 \\
\hline & $\begin{array}{l}\text { III.5.- Earthen architecture (rammed } \\
\text { earth \& mud bricks) }\end{array}$ & 1.0 & 1 & 1 & 1 & 1 & 2 & 0 \\
\hline & III.6.- Examples of intervention & 4.0 & 2 & 1 & 0 & 1 & 2 & 0 \\
\hline \multirow{3}{*}{$\begin{array}{l}\text { IV.- Modern building } \\
\text { rehabilitation }\end{array}$} & IV.1.- Concrete structures & 4.0 & 1 & 2 & 0 & 0 & 3 & 0 \\
\hline & IV.2.- Steel and cast iron structures & 3.0 & 1 & 2 & 0 & 0 & 3 & 0 \\
\hline & IV.3.- Examples of intervention & 3.0 & 2 & 1 & 0 & 1 & 2 & $\boldsymbol{0}$ \\
\hline \multirow{3}{*}{$\begin{array}{l}\text { V.- Seismic behavior } \\
\text { of historic buildings }\end{array}$} & $\begin{array}{l}\text { V.1.- Effects of earthquakes on } \\
\text { constructions: Pathological processes } \\
\text { due to recent earthquakes. }\end{array}$ & 2.0 & 1 & 2 & 0 & 0 & 2 & 1 \\
\hline & $\begin{array}{l}\text { V.2.- Methodologies for seismic safety } \\
\text { assessment of constructions. }\end{array}$ & 1.5 & 3 & 0 & 0 & 2 & 1 & 0 \\
\hline & $\begin{array}{l}\text { V.3.- Seismic strengthening solutions } \\
\text { for old masonry buildings and for } \\
\text { reinforced concrete buildings. }\end{array}$ & 1.5 & 2 & 1 & 0 & 2 & 1 & 0 \\
\hline \multirow{2}{*}{$\begin{array}{l}\text { VI.- Technology for } \\
\text { rehabilitation of non- } \\
\text { structural anomalies } \\
\text { in buildings } \\
\end{array}$} & $\begin{array}{l}\text { VI.1.- Humidity problems. Capillary, } \\
\text { condensation and filtration. } \\
\end{array}$ & 2.0 & 2 & 1 & 0 & 1 & 2 & 0 \\
\hline & $\begin{array}{l}\text { VI.2.- External building elements } \\
\text { (roofs and facades) }\end{array}$ & 3.0 & 2 & 1 & 0 & 1 & 2 & 0 \\
\hline \multirow[t]{2}{*}{$\begin{array}{l}\text { VII.- Control and } \\
\text { maintenance strategies }\end{array}$} & $\begin{array}{l}\text { VII.1.- Building control and } \\
\text { monitoring strategies: Control } \\
\text { program during the execution of the } \\
\text { intervention }\end{array}$ & 1.5 & 1 & 1 & 1 & 0 & 2 & 1 \\
\hline & \begin{tabular}{|l|} 
VII.2.- Building maintenance \\
strategies: preventive and corrective
\end{tabular} & 1.5 & 2 & 1 & 0 & 1 & 2 & 0 \\
\hline VIII.- Practical & $\begin{array}{l}\text { Visits to buildings in rehabilitation } \\
\text { and/or Workshops with other students } \\
\text { and professionals involved in } \\
\text { rehabilitation of historic buildings } \\
\text { and/or Practical work in Lab. }\end{array}$ & 4.0 & 3 & 0 & 0 & 1 & 2 & 0 \\
\hline
\end{tabular}

\section{Accepted Manuscript} Not Copyedited 
Table 3: Proposal of study hours in "Construction Rehabilitation", within Civil Engineering at the bachelor degree level.

\begin{tabular}{|c|c|c|c|c|c|c|c|c|c|}
\hline & & \multicolumn{8}{|c|}{ Blocks of topics } \\
\hline & & I & II & III & IV & $\mathbf{V}$ & VI & VII & VIII \\
\hline \multirow{3}{*}{$\begin{array}{l}\text { Face-to-face } \\
\text { hours: } 60 \mathrm{~h}\end{array}$} & Traditional lecture & 6 & 9 & 10 & 7 & 6 & 5 & 3 & - \\
\hline & Case studies* & - & 3 & 4 & 3 & - & - & - & - \\
\hline & Practice-based learning & - & - & - & - & - & - & - & 4 \\
\hline \multirow{4}{*}{$\begin{array}{c}\text { Out-of-class } \\
\text { hours: } 90 \text { h } \\
\text { (Autonomous } \\
\text { work) }\end{array}$} & Theoretical work & 7.5 & - & - & - & 7.5 & - & - & - \\
\hline & Practical work & - & 4 & - & - & - & 3.5 & - & - \\
\hline & Group work & - & - & 12.5 & 10 & - & - & - & - \\
\hline & Individual reflection & 5 & 9 & 10 & 7 & 6 & 5 & 3 & - \\
\hline & Total hours per block & 18.5 & 25 & 36.5 & 27 & 19.5 & 13.5 & 6 & 4 \\
\hline
\end{tabular}

* As Construction Rehabilitation is a field that is greatly influenced by practice, case studies may be taught by online learning by practicing engineers. 
Table 4: Methodology of teaching-learning

\begin{tabular}{|c|l|l|c|c|}
\hline Type & \multicolumn{1}{|c|}{ Name } & \multicolumn{1}{|c|}{ Description } & Hours & \% \\
\hline \multirow{2}{*}{} & Traditional lecture & $\begin{array}{l}\text { Presentation or explanation of contents by a teacher (possibly including } \\
\text { demonstrations) }\end{array}$ & 46 \\
\cline { 2 - 5 } & Case studies & $\begin{array}{l}\text { Technique in which the students analyze professional situations } \\
\text { presented by the teacher or practicing engineers, with the aim of } \\
\text { performing a conceptualization of experiences and searching for } \\
\text { efficient solutions. }\end{array}$ & 10 \\
\hline
\end{tabular}

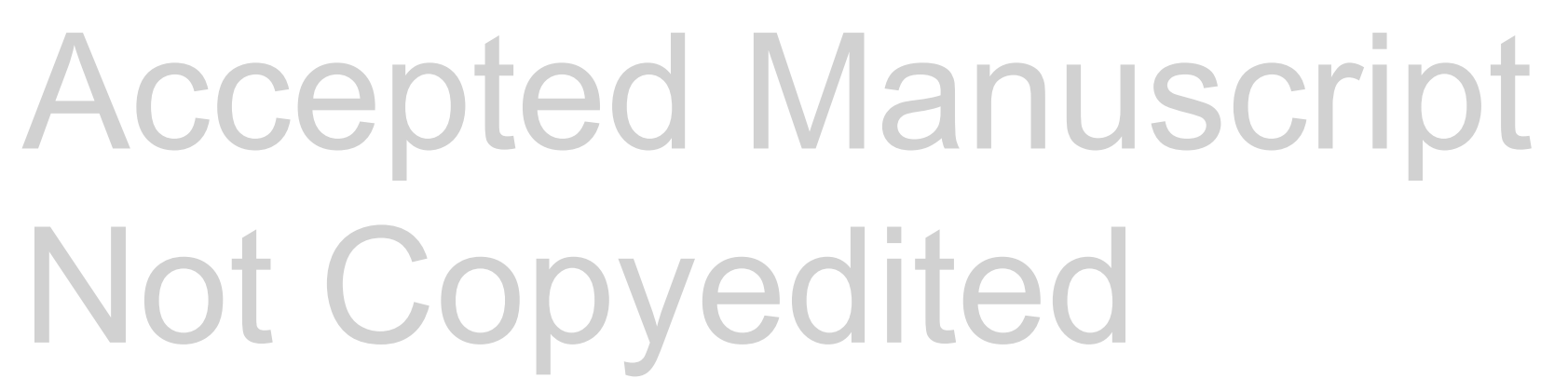


Table 5: Student evaluation

\begin{tabular}{|c|l|c|}
\hline Name & \multicolumn{1}{|c|}{ Description } & Weighting \\
\hline Academic work & $\begin{array}{l}\text { Performance of individual work / group works ranging from brief, simple } \\
\text { tasks to wide-ranging, complex tasks suitable for more advanced courses. }\end{array}$ & $50 \%$ \\
\hline Written test & $\begin{array}{l}\text { Timed test, carried out under invigilation, in which the students develop } \\
\text { their own answers, either with or without consultation material. }\end{array}$ & $50 \%$ \\
\hline
\end{tabular}

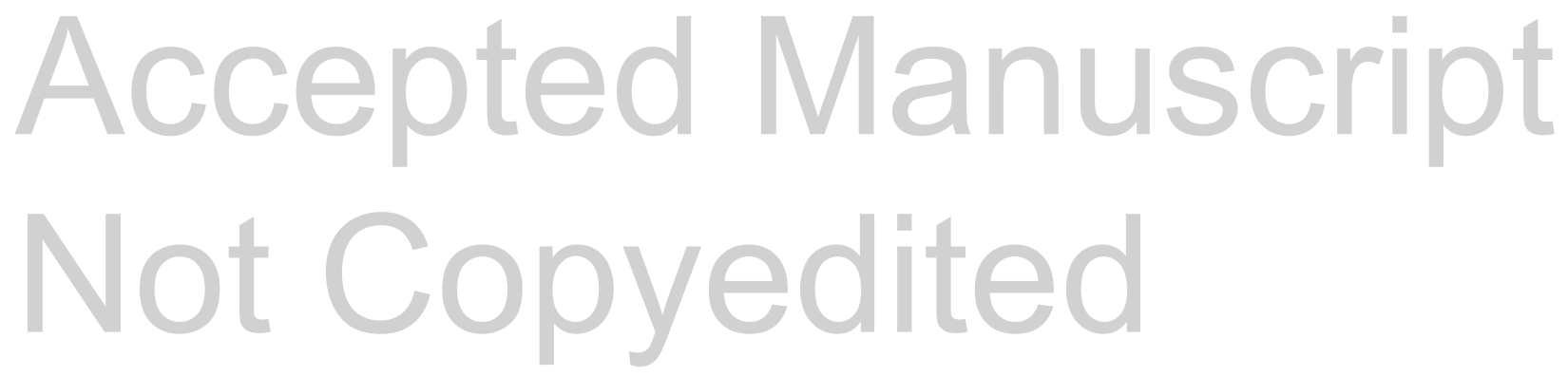

